\title{
Swelling Kinetics and Impregnation of PLA with Thymol under Supercritical $\mathrm{CO}_{2}$ Conditions
}

\author{
STOJA L. MILOVANOVIĆ, University of Belgrade, \\ Faculty of Technology and Metallurgy, Belgrade \\ ROBERT. M. KUSKA, Ruhr-University Bochum, \\ Institute of Thermo and Fluid Dynamics, Bochum, Germany \\ MARIJA LJ. LUČIĆ ŠKORIĆ, University of Belgrade, \\ Faculty of Technology and Metallurgy, Belgrade \\ MELINA T. KALAGASIDIS KRUŠIĆ, University of Belgrade, \\ Faculty of Technology and Metallurgy, Belgrade \\ SULAMITH FRERICH, Ruhr-University Bochum, \\ Institute of Thermo and Fluid Dynamics, Bochum, Germany \\ IRENA T. ŽIŽOVIĆ, University of Belgrade, \\ Faculty of Technology and Metallurgy, Belgrade \\ JASNA Z. IVANOVIĆ, University of Belgrade, \\ Faculty of Technology and Metallurgy, Belgrade
}

Original scientific paper

UDC: $615.479 .4: 678.1$

\begin{abstract}
The present work was aimed to study swelling kinetics of polylactic acid (PLA) and its impregnation with thymol in supercritical carbon dioxide $\left(\mathrm{scCO}_{2}\right)$ medium. The influences of temperature and soaking time on the swelling kinetics and impregnation yield of PLA cylindrical disc and film were investigated. Swelling experiments were performed in a high pressure view cell at $10 \mathrm{MPa}$ and temperatures of 40 ${ }^{\circ} \mathrm{C}, 60^{\circ} \mathrm{C}$ and $75^{\circ} \mathrm{C}$ for 2 to $24 \mathrm{~h}$. On the basis of swelling kinetics, pressure of $10 \mathrm{MPa}$ and temperature of $40^{\circ} \mathrm{C}$ were chosen for supercritical solvent impregnation (SSI) of the PLA samples during 2 to $24 \mathrm{~h}$. The highest swelling extent was observed for the PLA monolith after $24 \mathrm{~h}$ treatment with pure scCO $\mathrm{C}_{2}$ $(7.5 \%)$ and $\mathrm{scCO}_{2}$ with thymol (118.3\%). It was shown that sufficiently high amount of thymol can be loaded into both PLA monolith and film using SSI after only $2 \mathrm{~h}$ (10.0\% and 6.6\%, respectively). Monolith and film of PLA impregnated with thymol could be suitable for active food packaging and sterile medical disposables.
\end{abstract}

Key words: carbon dioxide, PLA, supercritical impregnation, swelling, thymol

\section{INTRODUCTION}

One of the most important trends in the polymer field nowadays is replacement of petroleum-based polymers with bio-based ones. Polylactic acid (PLA) has been very attractive for food packaging and biomedical applications being biocompatible and biodegradable polymer with relatively low cost production and good physical and mechanical properties. PLA is obtained on industrial scale by the ring-opening polymerization

Author's address: Stoja Milovanović, University of Belgrade, Faculty of Technology and Metallurgy, Belgrade, Karnegijeva 4

Paper received: 18.12.2015.

Paper accepted: 21.01.2016. of lactide, the cyclic dimer of lactic acid $[1,2]$. The ratio between the two stereoisomers, L-lactic acid and D-lactic acid, control the PLA properties, in particular crystallinity [2]. Crystalline level of the PLA modulates its permeability, mechanical performance, heat deflection temperature, and biodegradation rate. Due to mechanical strength, PLA has attracted interest as a packaging material. Also, its ability to slowly degrade in the human body makes it suitable for biomedical applications (e.g. tissue engineering scaffold) [1, 2].

Supercritical carbon dioxide $\left(\mathrm{scCO}_{2}\right)$ has been recently proven as advantageous medium for polymer processing [3]. Besides having low critical pressure and temperature $\left(\mathrm{P}_{\mathrm{c}}=7.38 \mathrm{MPa}\right.$ and $\left.\mathrm{T}_{\mathrm{c}}=31.1{ }^{\circ} \mathrm{C}\right)$, $\mathrm{scCO}_{2}$ is non-toxic, non-flammable, chemically inert, cheap, and easily available. $\mathrm{ScCO}_{2}$ is a good solvent 
for non-polar substances and has high diffusivity in solids. Therefore, $\mathrm{scCO}_{2}$ can be used as a solvent, foaming agent, and impregnation medium in polymer processing. Main advantages of polymers processing with $\mathrm{scCO}_{2}$ include working at low temperatures and with thermolabile and hydrophobic substances as well as fast and complete solvent removal from the final product [4]. Supercritical foaming process implies polymers saturation with a supercritical fluid at constant temperature and pressure conditions followed by rapid increase of temperature or reduction of pressure which may result in the nucleation and growth of gas bubbles inside the polymer matrix and thus creation of porous structures. Control of the pore structure is crucial because size and interconnectivity of pores strongly influence scaffolds cell growth behavior and drug release profile [1]. Supercritical solvent impregnation (SSI) implies dissolution of bioactive compounds in supercritical fluid and contact of the resulting fluid mixture with a polymer material to be impregnated [5]. A bioactive compound can be entrapped by a simple deposition into the polymer matrix after removal of the $\mathrm{scCO}_{2}$ from the system or via chemical interactions between the bioactive compound and the polymer that favors the impregnation [6]. Loading of the bioactive compounds or depth of their penetration can be modified by adjusting parameters such as solvent density (by changes in pressure and temperature), rate of the depressurization step, and the time of impregnation $[5,6]$. Incorporation of bioactive components into polymers enables production of materials with high added value with a wide range of use. One of natural compounds that proved to be appropriate for producing antimicrobial polymers is thymol [7-9]. Thymol has strong antimicrobial, antioxidant and antiinflammatory activity [10] and its use was approved by FDA.

This research was aimed to determine swelling behavior of PLA samples in the form of monolith and film and their impregnation with thymol under moderately high $\mathrm{scCO}_{2}$ pressure and temperatures in order to obtain functional material for use as active food packaging or in production of sterile medical disposables.

\section{EXPERIMENTAL WORK}

\subsection{Materials}

Semi-crystalline PLA (Ingeo 3052D, NatureWorks LLC, Germany) containing $4.15 \%$ of D-lactide monomer was used for this research. Thymol (purity $<99 \%$, Sigma Aldrich, Germany) was used for impregnation process. Chlorophorm (Centrohem, Serbia) was used for PLA film preparation. Comercial carbon dioxide (purity 99\%) was supplied by Messer-Technogas (Serbia).

\subsection{Methods}

\subsubsection{Preparation of PLA cylindrical monolith and film}

Cylindrical PLA monolith was obtained by premelting of PLA beads $(0.34 \mathrm{~g} \pm 0.05 \mathrm{~g})$ at $170{ }^{\circ} \mathrm{C} \pm 5$ ${ }^{\circ} \mathrm{C}$ and its moulding in the disc shaped glass for 15 minutes. Obtained PLA disc had ticknes of $3 \mathrm{~mm} \pm 0.5$ $\mathrm{mm}$ and diameter of $10 \mathrm{~mm} \pm 2 \mathrm{~mm}$.

Film of PLA was obtained by solvent casting method using chloroform as a solvent ( $1 \mathrm{~g}$ of PLA was disolved in $12.5 \mathrm{~mL}$ of chlorophorm). Solvent was evaporated at room temperature during $48 \mathrm{~h}$. Tickness of the obtained film was $0.20 \mathrm{~mm} \pm 0.04 \mathrm{~mm}$.

\subsubsection{Swelling of PLA and its impregnation}

A high pressure view cell equipped with $\mathrm{CCD}$ camera described elsewhere [8] was used to monitor swelling behavior and impregnation of PLA samples (Figure 1).

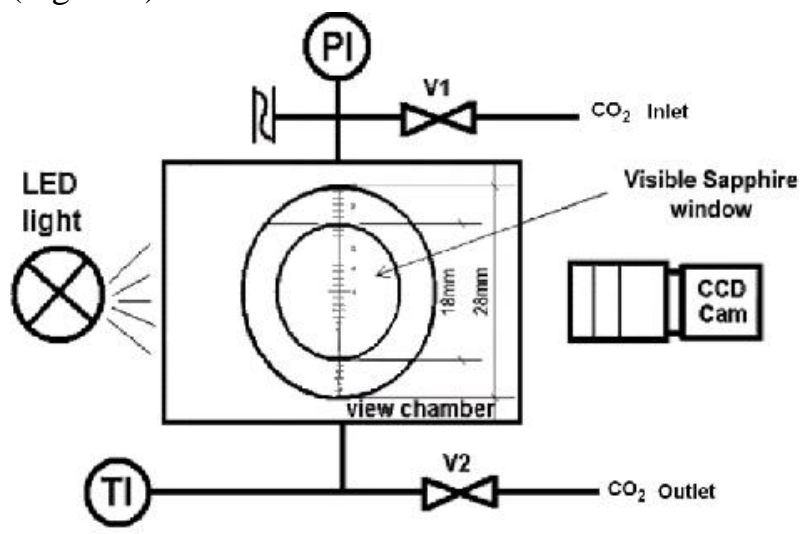

Figure 1 - View cell

Swelling behavior of PLA exposed to $\mathrm{scCO}_{2}$ was investigated at $10 \mathrm{MPa}$ and $40,60,75^{\circ} \mathrm{C}$. The time of exposure varied from $2 \mathrm{~h}$ to $24 \mathrm{~h}$. The volume changes of the samples exposed to $\mathrm{scCO}_{2}$ were monitored by recording the two-dimensional projection of the rotationally symmetric sample with time using the IC Capture 2.1 software. The change of the sample's dimension (height, $L$ ) due to swelling was determined by the image processing program ImageJ. Swelling extent $(S)$ was calculated using Eq. 1:

$$
S(\%)=\frac{V_{t}-V_{0}}{V_{0}} \cdot 100=\left(\frac{L}{L_{0}}-1\right) \cdot 100
$$

where $V_{0}$ is the volume of polymer at ambient conditions at the beginning of the process, $V_{t}$ is the volume of swollen polymer, $L_{0}$ and $L$ are the heights of polymer molded in the glass beaker at the beginning of the process and after swelling, respectively.

For monitoring of PLA swelling and impregnation in $\mathrm{scCO}_{2}$-thymol system, 1:1 PLA to thymol ratio was chosen. Thymol was placed at the bottom of the cell 
while PLA was placed above it. Pressure of $10 \mathrm{MPa}$ and temperature of $40{ }^{\circ} \mathrm{C}$ were applied during 2 to 24 h.

Impregnation yield ( $I)$ was calculated using Eq. 2:

$$
I(P, T, t)=\frac{m_{\text {Thymol }}}{m_{P L A}+m_{\text {Thymol }}} \cdot 100 \%
$$

where $m_{\text {Thymol }}$ is the mass of impregnated thymol and $m_{P L A}$ is the mass of polymer at the beginning of process. $m_{\text {Thymol }}$ was calculated as a difference between masses of the impregnated PLA sample and $m_{P L A}$.

\subsubsection{Scanning electron microscopy (SEM)}

Field emission scanning electron microscopy (FESEM, Mira3Tescan) was used to analyze morphology of the PLA disc and film treated with $\mathrm{scCO}_{2}$ and thymol. The samples were coated with a thin layer of $\mathrm{Au} / \mathrm{Pd}(85 / 15)$ prior to the analysis.

\section{RESULTS}

\subsection{Swelling behaviour of PLA}

Swelling kinetics of the PLA disc at pressure of 10 $\mathrm{MPa}$ and temperatures of $40{ }^{\circ} \mathrm{C}, 60^{\circ} \mathrm{C}$ and $75^{\circ} \mathrm{C}$ are presented in Figure 2.

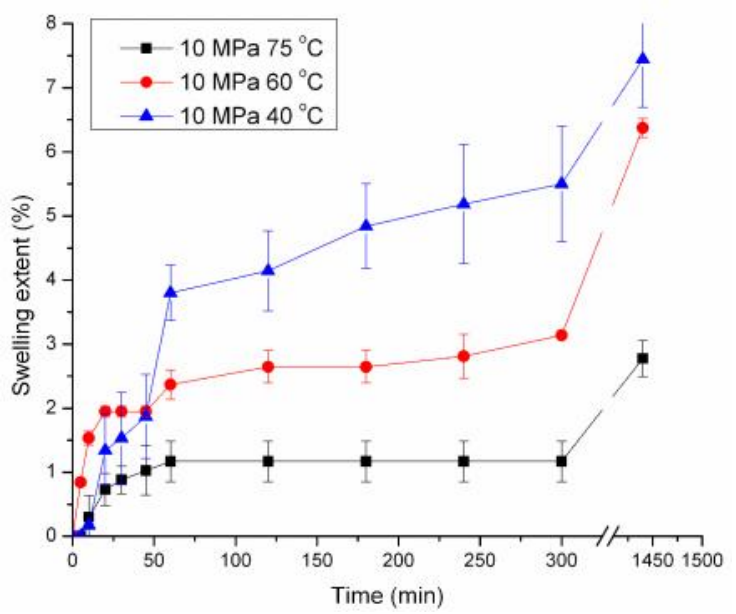

Figure 2 - Swelling kinetics of PLA monolith

Longer soaking time led to the higher swelling extent of the PLA disc while the temperature increase resulted in decrease of the swelling extent. Accordingly, the highest swelling extent $(7.45 \%)$ of the PLA disc at $10 \mathrm{MPa}$ was recorded after $24 \mathrm{~h}$ and at the lowest temperature tested $\left(40^{\circ} \mathrm{C}\right)$.

Swelling kinetics of the PLA disc and film at 10 $\mathrm{MPa}$ and $40^{\circ} \mathrm{C}$ are presented in Figure 3. It can be seen that the disc had 4.2 times higher swelling extent. The highest swelling extent of PLA was achieved after 24 h. Swelling extent of the PLA film reached its maximum of $1.75 \%$ after $6 \mathrm{~h}$.

The samples of PLA investigated in this study had higher swelling extent in $\mathrm{scCO}_{2}$ in comparison to previously reported at comparable pressure and temperature conditions (density of $\mathrm{CO}_{2}$ ) $[1,11,12]$.

PLA (PLA 52K, Purac) investigated by Pini and coworkers [11] had maximum swelling extent of $0.65 \%$ at $35{ }^{\circ} \mathrm{C}$ and $20 \mathrm{MPa}$, while swelling extent of PLA (PLA 15K, Resomer, and PLA 52K, Purac) investigated by Tai and coworkers [1] at same conditions was up to $0.68 \%$. Sato and coworkers [12] reported $0.20-0.55 \%$ swelling extent of PLA (PLA $117 \mathrm{~K}$ and $157 \mathrm{~K}$, Mitsui Chemicals, Inc.) at $40{ }^{\circ} \mathrm{C}$ and 6-20 MPa.

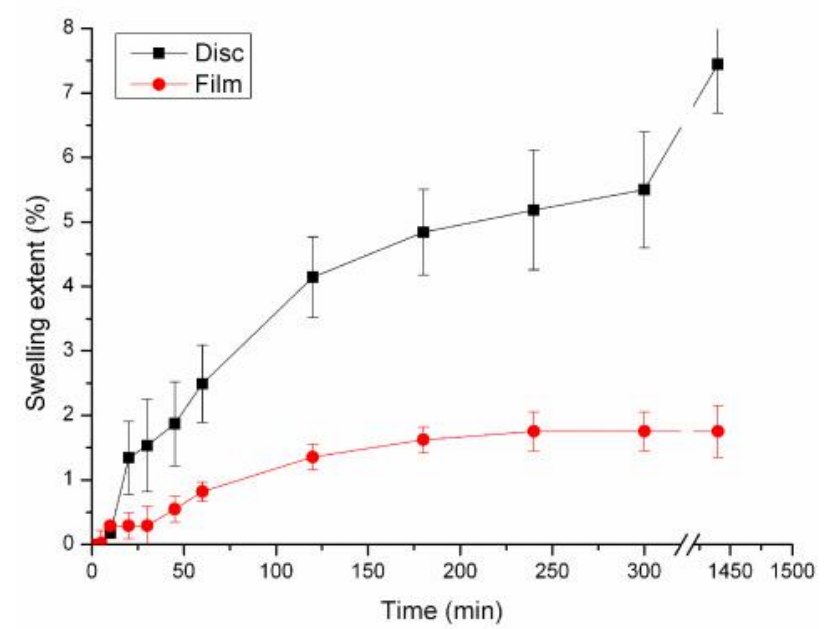

Figure 3 - Swelling kinetic of PLA disc and film at 10 $\mathrm{MPa}$ and $40^{\circ} \mathrm{C}$

$\mathrm{ScCO}_{2}$ solubility and diffusivity into PLA are influenced by both, the molecular structure (the interaction between $\mathrm{CO}_{2}$ and polymer chains) and the morphology (crystalline or amorphous, related with free volume) of polymers [1]. Shieh and Lin [13] suggested that the sorption process at or below Pc was mainly driven by carbonyl groups. Above Pc sorption process is driven by the degree of crystallinity in such way that the higher the degree of crystallinity, the lower $\mathrm{CO}_{2}$ solubility in the polymer will be.

\subsection{Supercritical solvent impregnation of PLA with thymol}

Pressure and temperature conditions for SSI of the PLA samples with thymol $\left(10 \mathrm{MPa}\right.$ and $\left.40{ }^{\circ} \mathrm{C}\right)$ were selected on the basis of previously determined solubility of thymol in $\mathrm{scCO}_{2}[8]$ and swelling behaviour of PLA (Figure 1). At these conditions, maximum impregnation yield for the PLA disc was $29.91 \%$ with $118.27 \%$ swelling extent obtained for $24 \mathrm{~h}$ indicating thymol effect on the PLA morphology.

Kinetics of the PLA disc impregnation with thymol is presented in Figure 4. Longer soaking time led to higher impregnation yield. This is in accordance with the previously observed positive effect of longer soaking time on the swelling of PLA (Figure 2) at the same conditions (10 MPa and $40{ }^{\circ} \mathrm{C}$ ). 


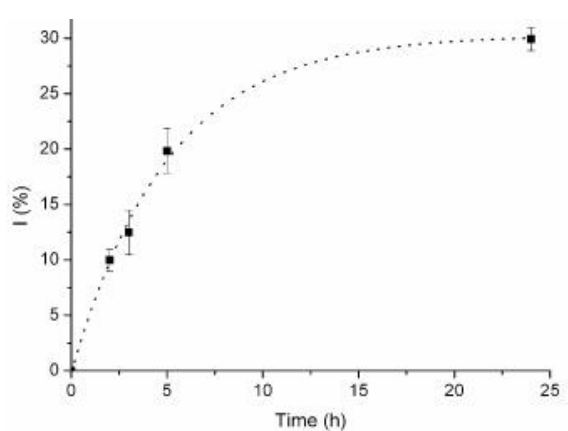

Figure 4 - Kinetic of thymol impregnation into PLA disc

The highest impregnation rate was observed within first 5 h reaching $20 \%$ of thymol impregnation yield in PLA. Impregnation yield of PLA disc after $24 \mathrm{~h}$ was $30 \%$. However, sufficiently high impregnation yield of the PLA disc was achieved already after $2 \mathrm{~h}$ $(10 \%)$ with the swelling extent $8.04 \%$. Namely, in our previous study impregnated cellulose acetate scaffold containing $4.51 \%$ of thymol provided antimicrobial action against Escherichia coli, Staphylococcus aureus, and Candida albicans [7]. Also, satisfactory impregnation yield of the PLA film (6.6\%) was achieved after only $2 \mathrm{~h}$ at same operating pressure and temperature $\left(10 \mathrm{MPa}\right.$ and $\left.40{ }^{\circ} \mathrm{C}\right)$. Therewith, swelling extent of the PLA film in the presence of $\mathrm{scCO}_{2}$ and thymol was only $1.20 \%$. Small swelling extent of the PLA film during SSI is desirable feature for film usage in food packaging. There are no data in the literature available on PLA impregnation with thymol using $\mathrm{ScCO}_{2}$. Sato and coworkers [12] impregnated PLA with paclitaxel at $40{ }^{\circ} \mathrm{C}$ and $20 \mathrm{MPa}$ during $24 \mathrm{~h}$ with $0.01 \%$ impregnation yield. Some of the recently reported thymol impregnated polymeric materials using $\mathrm{ScCO}_{2}$ at same conditions $\left(10 \mathrm{MPa}, 40{ }^{\circ} \mathrm{C}, 2 \mathrm{~h}\right)$ include: cellulose acetate with impregnation yield $4.51 \%$ [7], cotton gauze with impregnation yield $11 \%$ [8], polycaprolactone with impregnation yield $23.7 \%$ [3].

\subsection{Morphological analysis}

SEM images of PLA disc (Figure 5a) and film (Figure $5 \mathrm{~b}$ ) processed at $10 \mathrm{MPa}$ and $40{ }^{\circ} \mathrm{C}$ with pure $\mathrm{scCO}_{2}$ show that samples have almost flat surface without visible pores.

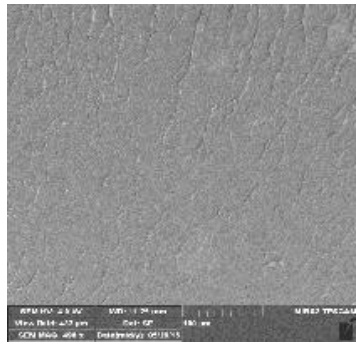

a)

Figure 5 - SEM images of PLA a) disc and b) film treated with pure $\mathrm{scCO}$

Comparable analysis of SEM images of PLA disc and film treated with pure $\mathrm{scCO}_{2}$ (Figure 5) and impregnated with thymol at $10 \mathrm{MPa}$ and $40{ }^{\circ} \mathrm{C}$ during $2 \mathrm{~h}$ (Figure 6) showed that thymol had small effect on PLA morphology at applied pressure and temperature conditions.

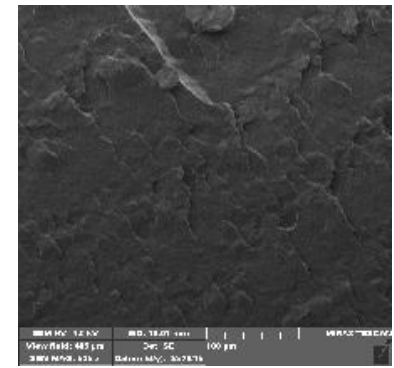

a)

Figure 6 - SEM images of PLA a) disc and b) film impregnated with thymol $(10 \%$ and $6.6 \%$, respectively)

\section{CONCLUSION}

The study provided new data on swelling kinetics of PLA in presence of $\mathrm{scCO}_{2}$ and thymol as well as the first data on SSI of PLA with thymol. The highest swelling extent with pure $\mathrm{scCO}_{2}$ was obtained at 10 $\mathrm{MPa}$ and $40{ }^{\circ} \mathrm{C}$. After $24 \mathrm{~h}$, PLA disc had higher swelling extent then film, $7.45 \%$ and $1.75 \%$, respectively. Thymol had pronounced effect on the PLA disc swelling at aforementioned conditions (118.3\%).

Feasibility of SSI for succesfull loading of sufficiently high amounts of thymol into both PLA disc $(10 \%)$ and film $(6.6 \%)$ after only $2 \mathrm{~h}$ was proven. Nonporous PLA disc and film impregnated with thymol have great potential for food packaging and production of medical disposals where sterile environment is required.

\section{ACKNOWLEDGMENT}

Financial support of the Serbian Ministry of Education, Science and Technological Development (Project No. III 45017 and OI172062) and German Academic Exchange Service (DAAD) is gratefully acknowledged.

\section{REMARK}

The paper was presented at the 14th Young researchers' conference, Materials science and engineering, Belgrade, December 9-11, 2015.

\section{LITERATURE}

[1] Tai H. Batch Foaming of Amorphous Poly (DLLactic Acid) and Poly (Lactic Acid-co-Glycolic Acid) with Supercritical Carbon Dioxide: CO2 Solubility, Intermolecular Interaction, Rheology and 
Morphology [Internet]. Rheology, InTech, China; 2012 [cited 25.12.2015]. Available from: http://www.intechopen.com/books/rheology/batch-foaming-of-amorphous-poly-dl-lactic-acid-and-poly-lactic-acid-co-glycolic-acid-with-supercriti

[2] Mihai M, Huneault MA, Favis BD, Li H. Extrusion foaming of semi-crystalline PLA and PLA/thermoplastic starch blends, Macromolecural Bioscience, Vol. 7, pp. 907-920, 2007.

[3] Ivanovic J, Knauer S, Fanovich A, Milovanovica S, Stamenic M, Jaeger P, Zizovic I, Eggers R. Supercritical $\mathrm{CO}_{2}$ sorption kinetics and thymol impregnation of PCL and PCL-HA, Journal of Supercritical Fluids, Vol. 107, pp. 486-498, 2016.

[4] Zizovic I, Ivanovic J, Milovanovic S, Stamenic M. Impregnations using supercritical carbon dioxide, in: Roj E. (Ed.), Supercritical $\mathrm{CO}_{2}$ extraction and its applications, Ch. 2, OIC Poland, Lublin, 2014.

[5] Kikic I, Vecchione F. Supercritical impregnation of polymers, Current Opinion in Solid \& Material Science, Vol. 7, pp. 399-405, 2003.

[6] Duarte ARC, Simplicio AL, Vega-González A, Subra-Paternault P, Coimbra P, Gil MH, de Sousa HC, Duarte CMM. Supercritical fluid impregnation of a biocompatible polymer for ophthalmic drug delivery, Journal of Supercritical Fluids, Vol. 42, pp. 373-377, 2007.

[7] Milovanovic S, Stamenic M, Markovic D, Ivanovic J, Zizovic I. Supercritical impregnation of cellulose acetate with thymol, Journal of Supercritical Fluids, Vol. 97, pp. 107-115, 2015.
[8] Milovanovic S, Stamenic M, Markovic D, Radetic M, Zizovic I. Solubility of thymol in supercritical carbon dioxide and its impregnation on cotton gauze, Journal of Supercritical Fluids, Vol. 84, pp. 173-181, 2013.

[9] Markovic D, Milovanovic S, Radetic M, Jokic B, Zizovic I. Impregnation of corona modified polypropylene non-woven material with thymol in supercritical carbon dioxide for antimicrobial application, Journal of Supercritical Fluids, Vol. 101, pp. 215$221,2015$.

[10]Dias AMA, Braga MEM, Braga IJ, Ferreira P, Gil MH, de Sousa HC. Development of natural-based wound dressings impregnated with bioactive compounds and using supercritical carbon dioxide, International Journal of Pharmaceutics, Vol. 408, pp. 919, 2011.

[11]Pini R, Storti G, Mazzotti M, Tai H, Shakesheff KM, Howdle SM. Sorption and swelling of poly(D,Llactic acid) and poly(lactic-co-glycolic acid) in supercritical $\mathrm{CO}_{2}$, Macromolecular Symposium, Vol. 259, pp. 197-202, 2007.

[12] Sato K, Yoda S, Oyama HT, Supercritical Impregnation of Anticancer Drug into Biodegradable Polymer, American Institute of Chemical Engineers, Food, Pharmaceutical and Bioengineering Division, pp. 495-501, 2008.

[13] Shieh YT, Lin YG. Equilibrium solubility of CO2 in rubbery EVA over a wide pressure range: effects of carbonyl group content and crystallinity, Polymer, Vol. 43, No 6, pp. 1849-1856, 2002.

\title{
REZIME
}

\section{KINETIKA BUBRENJA PLA I NJEGOVA IMPREGNACIJA TIMOLOM UPOTREBOM NATKRITIČNOG UGLENIK(IV)-OKSIDA}

\begin{abstract}
Prikazana studija je namenjena ispitivanju kinetike bubrenja polilaktida (PLA) i njegovoj impregnaciji timolom u natkritičnom ugljenik(IV)-oksidu $\left(n k C \mathrm{O}_{2}\right)$. Praćen je uticaj temperature $i$ operativnog vremena na kinetiku bubrenja i prinos impregnacije PLA cilindričnog diska i filma. Eksperimenti bubrenja su izvedeni u ćeliji za rad pod visokim pritiscima na $10 \mathrm{MPa}$ and $40{ }^{\circ} \mathrm{C}, 60^{\circ} \mathrm{C}$ i $75{ }^{\circ} \mathrm{C}$ od $2 \mathrm{~h}$ do 24 h. Na osnovu kinetike bubrenja, natkritična impregnacija uzoraka PLA timolom je izvedena na pritisku od $10 \mathrm{MPa}$ i temperaturi od $40{ }^{\circ} \mathrm{C}$ tokom 2 do 24 h. Najveći stepen bubrenja je imao PLA disk na $10 \mathrm{MPa} \mathrm{i} 40{ }^{\circ} \mathrm{C}$ nakon $24 \mathrm{~h}(7,5 \%)$ u sistemu sa čistim nkCO $i$ u sistemu sa timolom (118,3\%). Pokazano je da se dovoljno visok prinos impregnacije timola može postići nakon 2 h (10,0\% za disk $i$ 6,6\% za film). PLA u formi diska i filma impregnirani timolom su pogodni materijali za aktivno pakovanje hrane $i$ za sterilni medicinski pribor.
\end{abstract}

Ključne reči: ugljen(IV)-oksid, PLA; natkritična impregnacija, bubrenje; timol 